\title{
Safety Assessment of Questionable Food Additives in the Halal Food Certification: A Review
}

\author{
Siti Mariyam ${ }^{1 *}$, Huseyin Bilgic ${ }^{2}$, Ivonne M.C.M. Rietjens ${ }^{3}$, Devi Yuni Susanti ${ }^{4}$ \\ ${ }^{1,4}$ Department of Agricultural and Biosystems Engineering, Faculty of Agricultural Technology, Universitas \\ Gadjah Mada, Jalan Flora 1. Bulaksumur, Yogyakarta 55281, Indonesia \\ ${ }^{2}$ Halal Feed and Food Inspection Authority, Fijnjekade 225, Den Haag, 2521 DT/ 2500 BT, The Netherlands \\ ${ }^{3}$ Division of Toxicology, Wageningen University and Research, Stippeneng 4, Wageningen, 6708 WE, The \\ Netherlands

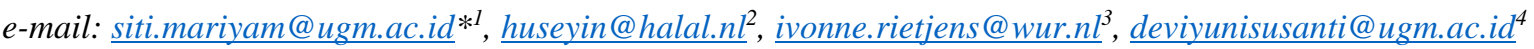 \\ *Corresponding Author \\ Received: September 15, 2021; Accepted: February 27, 2022
}

\begin{abstract}
Food additive demand was increased due to the higher need for long-lasting and ready-to-eat food. Some food ingredients are concerned about their halal status due to the source of ingredients and technology processes. Halal is not only related to the religious motif but also the food's integrity. This research aims to describe the scientific relevance of some questionable food additives in halal food certification in HFFIA (Halal Feed and Food Inspection Authority). The ingredients of food that have unclear halal status were subjected in this study. Literature reviews from some scientific sources for relevant papers in English were used to understand the suspected food additive. Food safety is included of certification process; it is essential for certificate application and verification procedures requirement. Food additives are used at food industry to enhance food quality. Some food additives have questionable halal status because of their principal ingredients. According to this study, those food additives were found in the screening process. The plant-based ingredients are good alternatives to ensure the halal status of those food additives. Also, the use of raw materials and processing aids from halal-approved origins and suitable processing technologies will provide the halal status and give the trustworthy among consumers. This review may serve as a basis for using food additives considering halal. It is not only for further research but also for food industry.
\end{abstract}

Keywords: food safety, halal, health, hygiene.

\section{Introduction}

State of The Global Islamic Economy Report (SGIE) 2020/2021 reported that the Muslim population spent around USD 2.2 trillion on halal products, such as food and beverages, medicines, and other lifestyle products that support the halal lifestyle. The prediction for 2024 is suspected that there will be the increase into USD 2.4 trillion. Halal food and beverage industry, cosmetics, medicines, Islamic financial services, fashion, halal tourism, and Islamic media are the significant role areas. Pandemic COVID-19 has affected the Muslims spend in 2020 significantly at the travel sectors $(70 \%)$, while food fares the best $(0.2 \%)$. Ready to eat meals and food delivery significantly increased by $219 \%$ to USD 6.3 billion (DinarStandards, 2020).

The demand of ready-to-eat meals and meal kits increased as the government's regulation to cook and eat at home due to pandemic COVID-19 situation. The use of food additives is essential to preserve food so that it can become ready-to-eat food and add other beneficial functions. Food additives are components which are added during food preservation to improve the shelf-life, flavor, savor, or food appearance. Food additives can be used if they have an appropriate technology. It will not misleads the consumers. Also it is used as a specific technical function (World Health Organization, 2018). Food additives sources are diverse. Because of that, they need to clarify the characteristics and origins of those components. The uncertainty of which raw materials, the food additives face an essential problem of halal food. Halal means allowance, proper, and permission. Halal foods are good foods for Muslim based on Islamic Law. It states that the foods are allowed and good for being the product.

In the intention of food, it is essential to consider both of quality and safety. Food safety is needed to guarantee human health and promote public health. The contaminants of food can enter the food supply chain during production, distribution, or consumption. Cleanliness and purity are essential in controlling food to promote human health. It is crucial to guarantee food authenticity to protect human health and consumer protection. The risk of food fraud increases the lack of the control operation or specific measurement as intended by management (Manning, 2016). Halal is one of the DOI: 10.15575/ijhar.v4i1.12097

https://journal.uinsgd.ac.id/index.php/ijhar/ 
concern issues. It is related to the religious motif and food integrity. Halal has provided the rules of cleanliness and purity of the raw materials from the products are made and the technology process. The safety of human life by eating healthy makes that halal become essential.

The specific aim of this review is to establish a scientific understanding of the properties of food about food safety and halal aspects. This paper elaborates on halal status of questionable food additives and related to food safety. This study is essential to provide scientific proof of halal authenticity. This study summarized the characteristics, chemical structure, toxicology, regulatory status, health concern, and possible alternatives for questionable food additives.

\section{Materials and Methods}

To specify a more precise context of food safety and halal status, this work reviews some questionable food additives food safety and halal status. The information gathered from the literature can recognize the challenges of halal food safety specifically. The list of compounds was collected from Halal Feed and Food Inspection Authority (HFFIA). It is an independent halal certification that works to assess halal requirements for worldwide companies. The compounds are chosen by according to their potency's unclear ingredients. Food additives with questionable halal status were the subject of this research. A literature review was conducted in Science Direct, Scopus, and Scholar for relevant papers in English. The methods are conducted comprehensively by using recurrent processes of describing relevant and revealing keywords, querying the literature, and undertaking rigorous analytics (Saunders et al., 2009).

\section{Results and Discussion}

The awareness in purchasing the safe food has increased among consumers. Also, the case of wholesomeness failures, such as unwanted harmless physical, chemical, or fraud ingredients raised. The manufacturer has to strengthen its control by providing brand quality protection. One of the best ways to guarantee quality is by certification. Halal certification ensures the produced product according to Islamic law. Based on Halal regulation, the use of food additives originating from animal sources has become a concern. For example, if the start of this fat comes from pork, it will be considered Haram. Besides, if it comes from the halal animal, the slaughtering procedure has to follow the method that has been described by Islam. There are some essential aspects to be considered in Halal certification since it is mentioned explicitly by the Halal regulation. Some animals are forbidden for Muslims. They are pigs, swine, dogs, donkeys, snakes, and cats. According to Islamic rituals that the materials which has come from animal ingredients should be taken from Halal animal species and slaughtered. Also alcoholic beverages, wines, spirits, and other intoxicants are prohibited.

Food safety has a strong correlation with halal concepts, which is related to the requirements for hygiene standards (Sani \& Dahlan, 2015). According to MS 1500:2009, hygiene, food safety, and sanitation are required at all stages of halal food production. Recently, the global food's supply chain certification is the best way to communicate product status (Manning, 2017). Nevertheless, the food industry also needs to stay in commiting to its food safety management. Food safety is a scientific control for the definition, preparation, and storage food in ways that avoid foodborne diseases. A farmto-table approach can reach food safety. The goal is to control hazards in the whole food production process. It is essential to prevent the contamination of the raw materials from plant or animal origin to ensure food safety (Chaves et al., 2017). Good Manufacturing Practice (GMP) or Good Hygiene Practice (GHP) implementation accompanied with Hazard Analysis and Critical Control Point (HACCP) during the food processing is essential to guarantee food safety (FAO, 2015). The halal certification implies that the whole process should follow hygienic and clean manners. It includes all the parts of the supply chain, such as the raw material, production, and distribution.

Hazard Analysis Critical Control Point (HACCP) is an approach to safety that addresses physical, chemical, and biological hazards for the prevention rather than final product inspection. It is recommended a strategy to improve food safety from farm to fork. This approach used by food industry to identify the food safety problems considers the Critical Control Points (CCP). This CCP describes factors that need specific attention and also the consumer requirements. Applying HACCP in Halal standard refers to the system guarantee food safety (Latif, 2014).

Food safety assurance is essential to preserve a safe and healthy food supply. It encompasses the total supply chain from raw materials to the finished product. It controls the quality of the raw materials and the critical processing elements. It guarantees that ingredients have quality and there are processes in place that are validated and monitored by concerning food safety (Batt, 2016). Foods and 
beverages which do not contain meat or alcohol naturally comply with halal criteria. Furthermore, some technological processes can lead the food being non-halal, for example, alcohol or food additives that are not halal. Food Safety Objective (FSO) describes an approach to set the elements of the HACCP system. The objective of FSO is to prevent sickness by focusing on food manufacturing and avoiding exposure to pathogens. FSO considered the entire process, including production, distribution, storage, and food consumption (Whiting \& Buchanan, 2014). Table 1 is informations about GAP between the food safety measurement and the halal standards.

Table 1. Scope of GMP, HACCP and Halal Standards

\begin{tabular}{|c|c|c|c|}
\hline & GMP & Standard Scope HACCP & Halal Standards \\
\hline Summary & $\begin{array}{l}\text { Guides towards developing a } \\
\text { safe food processing operation }\end{array}$ & $\begin{array}{l}\text { Directions on the processing } \\
\text { operation, including setting } \\
\text { parameters for secure food } \\
\text { processing, maintenance, and } \\
\text { troubleshooting procedures }\end{array}$ & $\begin{array}{l}\text { Introductory guides on Halal } \\
\text { for food processors with } \\
\text { emphasis on Islamic animal } \\
\text { slaughtering methods }\end{array}$ \\
\hline \multirow[t]{8}{*}{ Scopes } & $\begin{array}{l}\text { Premises and facilities } \\
\text { locations, premises, facilities, } \\
\text { and processing machines }\end{array}$ & $\begin{array}{l}\text { Analyze hazards- biologically, } \\
\text { chemically and physically }\end{array}$ & Najis terms definition \\
\hline & $\begin{array}{l}\text { Operation control - } \\
\text { developing standard operating } \\
\text { procedure }(\mathrm{SOP})\end{array}$ & Determine critical control points & $\begin{array}{l}\text { Define Management } \\
\text { responsibility }\end{array}$ \\
\hline & Sanitation and maintenance & $\begin{array}{l}\text { Establish limits for critical control } \\
\text { points }\end{array}$ & $\begin{array}{l}\text { Premises and machinery } \\
\text { hygiene }\end{array}$ \\
\hline & $\begin{array}{l}\text { Personnel - Hygiene and } \\
\text { training }\end{array}$ & $\begin{array}{l}\text { Establish monitoring procedures } \\
\text { for critical control points }\end{array}$ & Processing of Halal food \\
\hline & $\begin{array}{l}\text { Logistic - } \\
\text { compartmentalization and } \\
\text { maintenance }\end{array}$ & Establish corrective actions & Slaughtering process \\
\hline & GMP & Standard Scope HACCP & Halal Standards \\
\hline & Traceability system & Establish verification procedures & $\begin{array}{l}\text { Storage, transportation, } \\
\text { display, sale and servings of } \\
\text { Halal food. }\end{array}$ \\
\hline & Internal audit training & Establish a record system & $\begin{array}{l}\text { Packaging, labeling and } \\
\text { advertising }\end{array}$ \\
\hline
\end{tabular}

Food additives are components added during food preservation to improve the shelf-life, flavour, savour, or food appearance. Food additives can be obtained from natural sources, chemical synthesis, and biotechnological processes. In European Union, food additives indicated by "E" codes are followed by numbers expressing the chemical element (Moldes et al., 2017). The safety concept included the potential hazards to the health of human beings and needed the prove validation. There are some considerations to determine the safety of food additives: the intake of food additives, the effect of food additives on the food, the cumulative effect of food additives in human diet, and safety factors using the animal experiment data (Featherstone, 2015).

Food additives are essential in halal certification since the manufacturer usually uses them and has complex components. The halal issue of food additives is related to the raw materials origin and the technological process. The raw materials from animal derivate being the concern since some animals cannot be used as Halal food ingredients. In addition, insect-based food is also essential to be considered. Some of food additives which have a questionable halal status that found during HFFIA screening are E120 (Carmines), E441 (Gelatin), E542 (Edible Bone Phosphate), E471 (mono- and diglycerides), E483 (Stearyl tartrate), E422 (Glycerol), E904 (Shellac), E920 (L-Cysteine).

\subsection{E120 (Cochineal extract, Carminic, and Carmines)}

The categorized E number for food colouring is E100-E199. The exact colour is carminic acid, while the pigment's name is called carmine. Cochineal is a natural food colouring obtained from the female insect Dactylopius coccus Costa. This insect lives on cactus plants in some Peru and the Canary Islands (Ramesh \& Muthuraman, 2018). It was used widely as a food colourant since it has many advantages over other natural food colourants. Cochineal is one of the natural dye. It is soluble in water and can resist degradation through time. It has high stability through light, heat, and oxidation. It is even more stable than some synthetic colours.

The halal status of insects is not clear, except for locusts declared as Halal. Nevertheless, 
valuable insects such as bees, ants, and spiders, and dangerous or unclean animals like louse, flies, and midges are forbidden as food. Honey, as the product of insects, is suggested by the prophet to use in daily life to maintain health. Other accepted products such as wax, royal jelly, shellac, and carmine are approved to use, although some people may consider that carmine and shellac are debatable (Chaudry \& Riaz, 2014).

The cochineal uses in the form of food colourant can be replaced by artificial colours, for example, Erythrosine (E127), Allura Red, Carmoisine (E122), Ponceau 4R (E124), Amaranth (E123), Red 2G (E128), Brown FK (E154) and Iron oxides (E172). Besides, food colourants from plant-based ingredients can solve the consumer demand for natural food colourants. Natural food colouring, which is accepted in the European Union, consists of Carotenoids (E160), anthocyanins (E163), and betalains (E162) (Downham \& Collins, 2000). Furthermore, carotenoid red-coloured lycopene from tomatoes and capsanthin from paprika are more functional substituents than cochineal and its derivative (Müller-Maatsch \& Gras, 2016).

Carmines have a long history of being used as a food additive. The market for natural colourants is rising due to the consumer demand for natural products. Besides, carmine as a natural dye has some problems. The problems are related to the source of this additive, which is from an insect. Moreover, the Halal status of the carmine is questionable. Consumption of insects did not allow. There are some potential substitutes and future trends for the use of carmines. The artificial colourant is an alternative, but the consumer demands natural products. Hence, the use of plant-based dyes such as Carotenoids (E160), anthocyanins (E163) and betalains (E162). These colourants can be derived from plant origins such as red beet, papaya, tomatoes and paprika.

\subsection{E441 (Gelatin)}

Gelatin is a refined essence of collagenous tissue from various animals that form clear, sticky water solutions or just proteins of high pureness. It has no taste in either colour. The average humidity and temperature condition contains 9-13percent moisture and 1.3-1.4 relative density. During the heating in solution $40^{\circ} \mathrm{C}$, extremes $\mathrm{pH}$, and proteolytic enzymes, the effectiveness of gel and viscosity will be decreased (Featherstone, 2015). Gelatin has functionalities, such as gelling, binding, stabilizing, thickening, whipping, emulsifying, sticking, and foaming powder, syneresis prevention and thermos-reversibility in some food products, such as cookies, sweets, desserts, drinks, butter, ice cream, and cakes.

As an alternative, fish gelatine can be used in manufacturing. Fish gelatine is produced from the skin of deepwater fish. Moreover, it can be extracted from another fish part, such as the fish head and air bladder (Benjakul \& Kittiphattanabawon, 2019). This allows for having many same characteristics as animal gelatin. Furthermore, the alternatives can be from the fish skin, scales, and bones from the byproduct of aquatic products processing. Aquatic gelatin is a potential alternative for pork and beef gelatins since it has similar characteristics to mammalian gelatins. The improvement of aquatic gelatin properties is needed to be broaden of the use of aquatic gelatin in food production (Lin et al., 2017).

The transformation of gelatin only occurred physically, not chemically. Hence, istihalah of gelatin cannot be applied. Istihalah only be used if the change or transformation is entirely happened by physical and chemical aspects. The evolution of alcohol into the vinegar has wholly converted ethanol to another material and chemical product. In the auditing or physical inspection, for controling and checking the food race can be measured by laboratory analysis.

\subsection{E542 (Edible Bone Phosphate)}

Phosphate naturally presents organic esters in any food, such as meat, potatoes, bread, and other products. Only 40-60 percent phosphate is absorbed in the gastrointestinal tract. The source of this additive is animal bones. According to evaluation by FAO/WHO Expert Committee on Food Additives, E542 is a different residual combination of calcium phosphates, principally $\mathrm{Ca}_{3}\left(\mathrm{PO}_{4}\right)_{2}$ $\mathrm{Ca}(\mathrm{OH})_{2}$, gained by the grinding of bones that has been preserved with hot water and steam under pressure, may contain unextracted fat and proteins. Bone phosphate also includes some beneficial elements, such as fluorine and zinc. It has a white to pale colour and odourless powder form. It is not soluble in ethanol and water (FAO, 2013). It is considered a MacBook or questionable since the source of E542 is from animal bones. E542 cannot be used for vegans, vegetarians, Muslims, Jews or Hindus. It's usually made from pigs and cattle bones. To get the benefit from E 542 in food, some alternative anti-caking agents and emulsifiers originating from plant-based can be used. In addition, E 542 will be accepted if the supplier guarantees that the ingredients used for the manufacture come from a halal animal origin. 


\subsection{E471 (Mono- and Diglycerides)}

E471 is an artificial fat produced from glycerol and natural fatty acids. Mostly it is made from plant origin, but also animal origin may be used. The chemical structure of E471 from plant and animal origin have a similarity. Diglycerides are a minor natural constituent of many edible oils. They can combine hydrophilic and hydrophobic molecules. Diglycerides are glycerol esters in which two hydroxyl groups are esterified with long-chain fatty acids. (Ferretti et al., 2018).

E471 is used as emulsifiers and stabilizers commonly. It is used widely in products such as cakes and other bakery products, puddings, margarine, ice cream, and chocolate. This emulsifier is usually used to increase the volume and improve the crumb structure of baked goods and lengthen their shelf life. In the sauce dressing, it has the function to maintain the water and oil phase together, thus improving the appearance and shelf life (Nicholson \& Marangoni, 2018).

The use of animal origin, for example, pork, cannot be excluded. To make it clear, the producer may give specific information about the source of the fatty acids. If the fat source is soy fat, then it is halal. If the source is from pork fat, it is considered not Halal. To determine the fatty acid source, the manufacturer may specify by stating the origin of the fatty acids, whether it's made from plant or animal origin. The use of plant origin fatty acid is halal and permissible.

\subsection{E483 (Stearyl tartrate)}

E483 is a combination of stearic acid and tartaric acid. The synonym is Stearyl palmityl tartrate. The source of this additive can be plant and animal fat. Mostly, plant-origin has widespread used. The melting point of stearyl tartrate is between $67^{\circ} \mathrm{C}$ and $77^{\circ} \mathrm{C}$. After saponification, the saturated longchain fatty alcohol has a melting range of $49^{\circ} \mathrm{C}$ to $55^{\circ} \mathrm{C}$ (EC, 2012a).

It is used as an emulsifier, thickener, gelling agent and stabilizer in bakery products. Thereby, it can enhance the texture and quality of the food products. FAO set maximal level for some food categories, for dairy-based desserts (ice cream, ice milk, pudding, fruit or flavoured yoghurt), fatbased desserts, fruit-based dessert, vegetable and nut, cereal and starch-based desserts and egg-based desserts is $5000 \mathrm{mg} / \mathrm{kg}$, while for bakery wares is $4000 \mathrm{mg} / \mathrm{kg}$ (FAO, 2018). Stearyl tartrate is mostly made from vegetable oil, but the use of animal fat cannot be excluded. The producer should mention the origin of the fat to avoid ambiguousness. The use of plant-based ingredients that have the same function for the dough treatment could be an alternative.

\subsection{E442 (Glycerol)}

Glycerol is a polyalcohol containing three hydroxyls $(-\mathrm{OH})$ groups with the molecular formula $\mathrm{C}_{3} \mathrm{H}_{8} \mathrm{O}_{3}$. The boiling point is $290^{\circ} \mathrm{C}$. The physical appearance is clear, colourless, hygroscopic syrup liquid. Glycerol is natural alcohol from carbohydrates. It is the main component of fat (EC, 2012b). In the blood, it is presented in low concentrations.

Widely the application of glycerol is known as the low-calorie sweetener agent, food humidity, etc. Some products such as bakery and confectionery products use glycerol in their production. Glycerol is also used in meat products, sauces, flavoured drinks, gum, snack, chocolate, cereal, and food supplements. To determine the Halal status, information about its source is essential. It will be Halal if obtained from oils or soy fat. Glycerol is mainly originated from plants and animals sources, where it is present as triglycerides. Plant sources for glycerol production could be soybeans or palm trees.

\subsection{E904 (Shellac)}

Shellac is a purified secretion of lac insects, Laccifer lacca. It is used in tablet sealer, glazing agents, sweet, waxed fruit. Because of its ability to provide a glossy effect, shellac is commonly used to coat citrus and other fruit. Vegans usually avoid the product since there are lice in the raw product. Shellac is used and identified as a contact allergen in eye makeup. Plant-based ingredients can be a suitable alternative for halal food certification.

Plant-based ingredients can be a suitable alternative for halal food certification. Edible films and coating applications in food not only can increase product quality but also extend the shelf life of the product. The edible film can be classified according to the original material. Components for palatable film preparation can be classified as hydrocolloids (protein, polysaccharides, and alginate), lipids (fatty acids, glycerol, waxes), and composites (Dhall, 2013).

\subsection{E920 (L-Cysteine)}

Cysteine is categorized as a non-essential amino acid since sufficient amounts of cysteine can be produced by the cells in our body, under normal physiological conditions, from the dietary essential 
amino acid, L-Methionine, and the non-essential amino acid, L-Serine, via a transsulfuration reaction. (Paul et al., 2018). It is used as a bread enhancer. It can stabilize the structure of leavened bread. Cysteine is currently being used for applications within the food, pharmaceutical and personal care industries. One of the most significant applications in food industries is the production of flavours, such as the meat flavour in vegetarian foods (Alimentarius, 2015).

E920 is produced from animal sources. It has a crucial Halal issue. Therefore, a claim that cysteine from chicken feathers may be halal only if the feathers are from chickens slaughtered following the sharia. Cysteine can be produced by animal or plant origin. Plant-based ingredients will be suitable for vegans and another groups of religion like Muslims (Halal food) and Jews (Kosher food). Wacker (Germany) claims that they are the first company that produced L-Cysteine for vegans. This is a plant-based L-Cysteine produced by fermentation of vegetable materials and inorganic trace elements (Wacker, 2018).

\section{Conclusion}

The Halal requirement consists of the wholesomeness concept, which requires purity and freecontamination in whole production. Briefly, food safety is included in certification process. It has an important invention in the requirement for certificate application and verification procedures. According to this study, some food additives with uncertain halal status are often found in the screening process. The plant-based ingredients are good alternatives to ensure the halal recognition of those food additives. Also, the use of raw materials and processing aids from halal approved origins and suitable processing technologies will provide the halal status and give trust among consumers.

\section{Acknowledgements}

The authors thank the HFFIA management for allowing us to do an internship in this respectful institution. Furthermore, thank you for Indonesia Endowment Fund for Education (LPDP) scholarship for providing the funding to do master study in Wageningen University and Research.

\section{References}

Alimentarius, Codex (2015) General standard for food additives CODEX STAN 192-1995, adopted in 1995, revision 2015. Food and Agriculture Organization of the United Nations, Rome, and World Health Organization, GenevaBatt.

Batt, C. A. (2016). Food Safety Assurance. Reference Module in Food Science. Elsevier https://doi.org/10.1016/B978-0-08-100596-5.03442-9

Benjakul, S., \& Kittiphattanabawon, P. (2019). Gelatin, Encyclopedia of Food Chemistry, Pages 121127.

Chaudry, M. M., \& Riaz, M. N. (2014). Safety of Food and Beverages: Halal Food Requirements. Reference Module in Food Science: Encyclopedia of Food Safety, 3, 486-491. https://doi.org/10.1016/B978-0-12-378612-8.00400-5

Chaves, R. D., Alvarenga, V. O., Campagnollo, F. B., Caturla, M. Y. R., Oteiza, J. M., \& Sant'Ana, A. S. (2017). Food Safety Current Developments in Biotechnology and Bioengineering (pp. 245259).

Dhall, R. K. (2013). Advances in Edible Coatings for Fresh Fruits and Vegetables: A Review. Critical Reviews in Food Science and Nutrition, 53(5).

DinarStandards. (2020). State of the Global Islamic Economy Report 2020/21. Dubai Islamic Economy Development Center.

Downham, A., \& Collins, P. (2000). Colouring our foods in the last and next millennium. International Journal of Food Science \& Technology, 35, 5-22.

EC. (2012a). COMMISSION REGULATION (EU) No 231/2012 of 9 March 2012. Official Journal of the European Union, 22(3).

EC. (2012b). COMMISSION REGULATION (EU) No 231/2012 of 9 March 2012. Retrieved July 10, 2018, from https://eur-lex.europa.eu/legal-content/EN/TXT/?uri=celex:32012R0231.

FAO. (2013). Bone Phospate. Retrieved July 10, 2018, from www.fao.org/fileadmin/user_upload/jecfa_additives/docs/.../Additive-057.pdf

FAO. (2015). Food Safety \& Quality at FAO.

FAO. (2018). STEARYL TARTRATE. Retrieved July 10, 2018, from http://www.fao.org/docrep/meeting/005/Y0474S/y0474s6i.htm

Featherstone, S. (2015). A Complete Course in Canning and Related Processes (Fourteenth Edition) 
(Vol. 2, pp. 147-211).

Ferretti, C.A., Spotti, M.L. \& Cosimo, J. I. D. (2018). Diglyceride-rich oils from glycerolysis of edible vegetable oils. Catalysis Today, 302, 233-241. https://doi.org/10.1016/j.cattod.2017.04.008

Latif, A. I. (2014). A comparative analysis of global Halal certification requirements. Food Products Marketing, 20, 85-101.

Lin, L., Regenstein, J. M., Lv, S., Lu, J., \& Jiang, S. (2017). An overview of gelatin derived from aquatic animals: Properties and modification. Trends in Food Science \& Technology, 68, 102112.

Manning, L. (2016). Food fraud: policy and food chain. ScienceDirect, Food Science 2016, 10, 16-21.

Manning, L. (2017). Food integrity. British Food Journal, 119(1), 2-6.

Moldes, A. B., Vecino, X., \& Cruz, J. M. (2017). Nutraceuticals and Food Additives Current Developments in Biotechnology and Bioengineering (pp. 143-164). Vigo Pontevedra, Spain.

Müller-Maatsch, J., \& Gras, C. (2016). 18 - The "Carmine Problem" and Potential Alternatives1 Handbook on Natural Pigments in Food and Beverages Industrial Applications for Improving Food Color (pp. 385-428).

Nicholson, R. A., \& Marangoni, A. G. (2018). Digylcerides Reference Module in Food Science.

Paul D., Sbodio, J., \& H.Snyder, S. (2018). Cysteine Metabolism in Neuronal Redox Homeostasis. Cysteine Metabolism in Neuronal Redox Homeostasis, 39(5), 513-524. https://doi.org/10.1016/j.tips.2018.02.007

Ramesh, M., \& Muthuraman, A. (2018). Chapter 1 - Flavoring and Coloring Agents: Health Risks and Potential Problems Natural and Artificial Flavoring Agents and Food Dyes (pp. 1-28).

Sani, N. A., \& Dahlan, H. A. (2015). Current Trend for Food Safety and Halal Measures. ASEAN Community Conference 2015, Bangi, Malaysia, 11-12 November 2015.

Saunders, M., Lewis, P., \& Thornhill, A. (2009). Research methods for business students (5th ed.). Harlow: Pearson Education.

Wacker. (2018). Germany Patent. https://www.wacker.com/h/medias/6699-EN.pdf

Whiting, R. C., \& Buchanan, R. L. (2014). Food Safety Objective. Encyclopedia of Food Microbiology (Second Edition), 959-963. https://doi.org/10.1016/B978-0-12-384730-0.00395-5

World Health Organization. (2018). Food Additives. Retrieved Januari 2, 2022, from https://www.who.int/news-room/fact-sheets/detail/food-additives

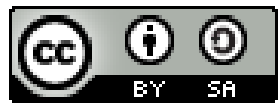

(C) 2022 by the authors. Submitted for possible open access publication under the terms and conditions of the Creative Commons Attribution (CC BY SA) license (https://creativecommons.org/licenses/by-sa/4.0/). 